\title{
Tragedy Sentimentalism 1965 Short Story in Nyanyian Penggali Kubur by Gunawan Budi Susanto
}

\author{
Mulyono $^{1}$ \\ \{1 sendang_bagus@mail.unnes.ac.id\} \\ ${ }^{1}$ Indonesian Language and Literature Department, Languages and Arts Faculty, Universitas Negeri \\ Semarang
}

\begin{abstract}
The stigma towards the PKI's hereditary until now is still a ghost in our social, national and state life. How many potential children of the nation must bear the burden of history, even they are in difficulties of treading a career. This story has been written by many Indonesian writers. People who experience trauma, anything can evoke the events that cause him trauma, including song lyrics. Gunawan Budi Susanto made three songs, namely " IlirIlir " (Sunan Kalijaga), " Ayah " (Charles Hutagalung), and "Kalian Dengar Keluhanku""(Ebiet G. Ade) in constructing the short story" Nyanyian Penggali Kubur ". The hermeneutic approach is used to explore the inner meaning of the text. Even though without saying the words of the PKI, we can easily associate the emotional turmoil of the characters who tend to be sentimental in the short story related to the traumatic life of victims of the G/30/S/PKI stigma events. The problem is how the author responds and uses these three songs in constructing the story. The hermeneutic approach is used to explore the inner meaning of the text, by considering elements of the text, the background of creating the text, the environment of the text, the relationship with other texts, and the dialogue of the text with the reader (the interpreter, the meaning giver). The conclusion is that even without telling a lot about PKI, we can relate the emotional of the characters who tend to be sentimental when responding and overcoming the three songs related to the traumatic life of the $1965 \mathrm{G} / 30 \mathrm{~S} /$ PKI stigma victims. We are invited to ponder how much our responsibility is to uphold universal values of humanity, justice and peace.
\end{abstract}

Keywords: sentimentalism, hermeneutics, nyanyian penggali kubur

\section{Introduction}

The G.30.S / PKI incident was a very terrible tragedy for the journey of the the nation and state, hundreds of thousands and even millions of children became victims of this event and this was a human tragedy and a violation of human rights [1]. According to Kammen, Mc Gregor, and the Asian Studies Association of Australia in 2012, at the end of 1965, the eradication was massive, it is estimated of 100,000 people those were detected by the PKI and were killed, and 70,000 people were arrested in Central Java. There were around 200,000 killed in East Java and another 25,000 were arrested. During the operation, it was estimated 
that around 80,000 people died or around 5 percent of the local population in Bali. Meanwhile, in North Sumetera, there were around 15,000 people killed, including Chinese ethnic, and around 15,000 others were arrested [2]. It caused [3] bitter experience or traumatic event often haunts the journey of human life. Although it has been buried deeply, bad events at certain moments can be recalled. The recalled by Song. In a song especially song lyrics, there is a process of exchanging information. Song lyrics can be used as an important description of social reality, it means that it is beneficial for humans to monitor the existence and relationship of their relationships in the reality of social life [4]. Song lyrics are powerful vehicles that can evoke sentimentalism in the past, including tragedy. In fact, a song that is actually not directly related, someone can be baper (carried away by feelings) in enjoy it.

Could it be that an author exactly use the song lyrics for horse riding in the work ? In his films, Rhoma Irama is simultaneously singing and telling stories. However, there may be a song lyrics first, then stories are created, or vice versa. The song became the soundtrack. In the context of authorship song lyrics can be a source of inspiration and creativity. Aminuddin [5] argues that the authors have the creativity of each and every works which are produced pay attention to the novelty and socio-cultural development.

The song became a vehicle for generating sentimentalism. Sentimentalism shows a view of human nature that puts forward the feeling, in addition to the mind. A sense of personality instills full of tenderness and affection, which upholds universal human values so that the author feels he can carry out social responsibility. The author in his work provides a great place to feel. Sentimental character merges in writing, in its creative work. Sentimentalism for an author is a treasure of the soul. Emotional turmoil is allied with a sense of dreams and wateriness. His works can be manifestations of touch, excited feeling, when other people do not have the same response to something .

Sentimentalism is certainly not just a cruel cry that is influenced by a sense of sentiment to influence feelings, which are usually mistakenly attached to the female person. In literature, sincerity, sympathy for the poor, upholding universal human values, it is also sentimentalism. Sentimental writers criticize cruel attitude and social injustice. The genre of sentimentalism is a subordinate of emotion. Authors have creative freedom to choose their feelings and express their ideas.

It is interesting to look at the short story "Nyanyian Penggali Kubur" by Gunawan Budi Susanto with a hermeneutic approach. Gadamer [6] revealed three principles. First, the results achieved in the work of hermeneutics (cultural work) are the inner spirit of the text, the deepest message of the text. Second, hermeneutics is not just a retelling; text writers, cultural producers, do not have to be real interpreters of the reality presented. Third, interpreters, giving cultural significance, we are all cultural workers, like the creators of history. We must be able to become "creators" of the text again. For this reason, the process of understanding is always changing and developing.

Benny H. Hoed [7] provides formulations, by combining semiotics and hermeneutics, the process of understanding the cultural meaning can be based on (1) the elements which are forming the text (cultural signs), (2) the background of the text production, (3) the text environment, (4) links to other texts, and (5) dialogue of texts with readers (interpreters, the giver of meaning).

It can be said that approaching literary texts by hermeneutics is approaching it from various directions, including from the psychological aspect. In writing their works, the authors certainly present characters with unique characters and behaviors to add to the appeal of the story. This aspect was raised by the psychology of literature as study material, especially regarding to the background of the actions and thoughts of the figures in related to the literary 
works. Wellek [8] explains that the psychology of literature has four meanings. First, literary psychology is the author's psychological understanding as a person or type. Second, an assessment of the creative process of the paper. Third, an analysis of the psychological laws applied in literary works. And fourth, the psychology of literature is also interpreted as a study of the impact of literature on the mental condition of readers.

The short story entitled "Nyanyian Penggali Kubur" by Gunawan Budi Susanto [9] is interesting to be analyzed because the author responds and overcomes to three songs in constructing his work. The three songs, namely Ilir-Ilir (Sunan Kalijaga), Ayah (Charles Hutagalung), and Keluhanku (Ebiet G. Ade).

\section{Research Method}

This study uses a hermeneutic approach. Gadamer stated that there are three principles. First, the results achieved in the hermeneutics work (cultural work) are the inner spirit of the text, the deepest message of the text. Second, hermeneutics is not just a retelling; text writers, cultural producers, do not have to be real interpreters of the reality presented. Third, interpreters, cultural meaning givers, we are all cultural workers, like the creators of history. We have to be able to become "creators" of the text. Based on this reason, the process of understanding is always changing and developing.

Benny $\mathrm{H}$. Hoed gave formulations, by combining semiotics and hermeneutics, the process of understanding cultural meaning can be based on (1) the elements of the text (cultural signs),

(2) the background of producing text, (3) the text environment, (4) relation to other texts, and

(5) texts dialogue with readers (interpreters, meaning giver).

It can be concluded that approaching literary texts by hermeneutics is approaching it from various fields, including from the psychological aspect. In writing their works, the authors certainly present characters with unique characters and behaviors to add to the attractiveness of the story. This aspect was raised by the literature psychology as study material, especially regarding to the background of the actions and thoughts of the figures in related literary works. Wellek explained that the literature psychology has four meanings. First, literary psychology is the author's psychological understanding as a person or type. Second, an analysis of the creative process of the literature work. Third, an analysis of the psychological laws applied in literary works. And fourth, the literature psychology is also interpreted as a study of the literature impact on the mental condition of readers.

\section{Results And Discussion}

The story is certainly full of emotional power and sentimentalism when it was written by people with the perspective of the victim, such as "Nyanyian Penggali Kubur". However, the sentimentalism that was intended was certainly not a bitter sentimentalism, but the manifestation of sentimentalism possessed by people (who wanted to) have a healthy personality. Erich Fromm argues that healthy personality traits, namely loving oneself fully, creatively, having the ability of mind to be able to develop, being able to observe the world and itself objectively, being able to relate to the world, free from discordant bonds, and being subject from oneself and destiny [10]. 


\subsection{Riding a Song}

Short story "Nynayian Penggali Kubur" utilizes three song lyrics with their respective functions in the ingredients and relations of events, conflicts, characters, plot, and settings, namely Ilir-Ilir (Sunan Kalijaga), Ayah (Charles Hutagalung), and Kalian Dengarlah Keluhanku ( Ebiet G . Ade ).

It is told, the gravedigger for 44 years always sings " Ilir-Ilir" in completing his work. Whoever dies, wherever they die, no matter what kind of death fetches them, he remains and continues to dig the grave. This song is to frame the characters who are patient and sincere to live the play. Ilir-ilir lir-ilir/tandure wus sumilir/tak ijo royo-royo/tak sengguh penganten anyar// Cah angon, cah angon/penekna blimbing kuwi/lunyu-lunyu penekna/kanggo mbasuh dodotirall Dodotira, dodotira/kumitir bedhah ing pinggir/dondomana jlumatana/kanggo seba mengko sorell Mumpung padhang rembulane/mumpung jembar kalanganel/ Yo suraka/surak hore//

The translation and denotative translation of the song's lyrics is that the plant (rice) has moved little by the breeze. Looks like a new green carpet. $O$ shepherd, climb the star fruit. Slippery indeed, but climb to wash your cloth. Your cloth that is torn at the edge of the sewing is to deal with this evening. While the moon is bright, while the opportunity is wide. Let's cheer hooray. In Javanese cultural society, the song has been incarnated as spell. Sunan Kalijaga, Javanese spiritual icon, is believed as its creator. The meaning which is contained in it is the time to immediately fight for the afterlife. Let's be happy.

In general, the song "Ilir-Ilir" is intended to foster peace of mind, calming the soul . This song is multifunctional, in addition to encouragement, it can put the child to sleep, even though the meaning is unrelated, to pacify the troubled soul so as to surrender. Grave diggers need it after discovering the reality of a bitter event.

"You know, after you die, you lose your sanity. He walked through the city streets day and night. Look for your father, "he said. "He eats by scavenging every pile of rubbish, under the hot sun, in the pouring rain. One time, my mother was found lying on the banks of this river. Died. I buried her, alone. Since then I decided to become a gravedigger. "

The next song is titled "Ayah". This song is to tread the next groove. People were curious, why the Gravedigger did not sing the song as usual, which is "Ilir-Ilir". The Gravedigger sings the song "Ayah" which is usually sung by Charles Hutagalung as follows: Di mana akan kucari/aku menangis seorang diri/hatiku slalu ingin bertemu/untukmu aku bernyanyi// Untuk Ayah tercinta/aku ingin bernyanyi/walau air mata di pipiku/l Ayah, dengarlah/aku ingin berjumpa/walau hanya dalam mimpi// Lihatlah, hari berganti/namun tiada seindah dulu/datanglah, aku ingin bertemu/untukmu aku bernyanyi//

This song is an introduction to describe the psychological turmoil of the Gravedigger. The inner conflict is the longing of the human child for the father. Imagined the father's bad luck at the end of the story is described below: "On this river, first, 44 years ago, I saw the bodies of my Father drifting somewhere. He was tucked between dozens of other corpses. But I'm sure, that's the body of my Father. They killed and threw his body into this river, " he said.

In another part it is expressed as follows.

"I do not want those people not to be buried properly like my Father. There is no reasons for anyone to let someone die without being properly buried. Whatever their religion, whatever their beliefs. But you are chiming in to other people making such a fuss about why I only mumbled songs for years, then suddenly now I sing. Is there nothing more important than to take care of other people's hinterland?" He said.

The next song sung by the Gravedigger is "Kalian Dengar Keluhanku" (Ebiet G.Ade): Dari pintu ke pintu/kucoba tawarkan nama/demi terhenti tangis anakku/dan keluh 
ibunya// Tetapi nampaknya semua mata/memandangku curiga/seperti hendak telanjangi/dan kuliti jiwaku/l Apakah buku diri ini/harus selalu hitam pekat/apakah dalam sejarah/orang mesti jadi pahlawan/sedang Tuhan di atas sana/tak pernah menghukum/dengan sinar matanya yang lebih tajam/dari matahari// Ke manakah sirnanya/nurani embun pagi/yang biasanya ramah/kini membakar hati// apakah bila terlanjur salah/akan tetap dianggap salah/tak ada waktu lagi benahi diri/tak ada tempat lagi untuk kembali// Kembali dari keterasingan/ke bumi beradab/ternyata lebih menyakitkan/dari derita panjang// Tuhan bimbinglah batin ini/agar tak gelap mata/dan sampaikanlah rasa inginku/kembali bersatu.

This song actually carries the meaning of repenting and criticizing people who sometimes do not accept former criminals living in a just society. In the context of this short story actually it carries the hope that the community does not create a constant stigma against PKI people and their children.

During the New Order administration, the focus of the "1965 Tragedy" discussion was only on the G/30/S/ PKI Event. A mental framework was built about a sharp dichotomy between heroes and traitors. The emphasized tragedy of 1965 was the death of six generals and an officer in the $\mathrm{G} / 30 / \mathrm{S} / \mathrm{PKI}$ incident and torture in Lubang Buaya. Two other humanitarian tragedies, which caused far more casualties, namely the mass killings of postG30S communists and exile to Buru Island were not considered humanitarian tragedies and were not taught in Indonesian National History textbooks. Mass killings, torturing, exiling the communists, and then the marking of stigma or "ex-prisoners" (ET) and "forbidden organizations" (OT) are seen by the New Order authorities as logical, natural, proper, or even according to Divine will. Therefore, during the period of its rule, Soeharto and the New Order supported by his organic intellectuals indoctrinated an ideology of hatred for anything related to the PKI, as well as brainwashing about the truth of military action against the communists. Indonesian society are always taught to be vigilant, afraid, and hate to the ghosts whose names are PKI.

The gravediggers deplore those who are not brave and lose the universal values of humanity because they are so afraid. "Nobody dared to pull over the bodies so they could be buried properly. Nobody. Dozens of corpses, dozens of corpses, so that the river water is red, bloody mud. "

\subsection{The Inner Background of the 1965 Tragedy and beyond}

The 1965 tragedy was a huge dark event in the history of the Indonesian people. The event not only left physical wounds but also mental wounds resulting from the carrying of this nation in the current and atmosphere of political violence. Even though the PKI does not mention the word at all, readers of the short story "Nyanyian Penggali Kubur" who are literate in history will easily direct their minds to the dark events of the nation's history.

History belongs to the rulers. The phrase seems normal for a country like Indonesia; a country where the overthrow of power, a race of ideological influence, and a bloody revolution have taken place. Of course we understand that the bloody revolution was the period of 1965, after the events of the September 30th Movement, and several years after. During this period there were mass arrests and killings of people accused of being communists, according to Robert Cribb reaching 78,000 to two million people [11].

In fact many Indonesian writers see the fate of PKI people or those accused of PKI from a humanitarian perspective, for example Ronggeng Dukuh Paruk (Ahmad Tohari), Pulang (Laila S. Chudori), Amba (Laksmi Pamuntjak), Cantik Itu Luka (Eka Kurniawan), and etc. Besides novels, there are also many short stories that raise the tragedy of humanity as the impact of the 1965 incident. 


\subsection{Stories from the Victim's Perspective}

Gunawan Budi Susanto or often called as Kang Putu, besides being a writer, he is also a journalist. He has a bitter life experience about the events of 1965 and thereafter. He was born in Blora, which is also the birthplace of the great Indonesian writer Pramudya Ananta Toer. At his shop, he opened a creative writing and intensive reading class by Pramudya Ananta Toer, a writer who was accused of being affiliated with the PKI. There is an emotional bond between Pram and Kang Putu. In addition to being both were born in Blora, both of them feel victimized.

Therefore, looking at the short story "Nyanyian Penggali Kubur" is impossible to escape from the psychological problems that surround it. The naming of the character "Penggali Kubur" (Gravedigger), not Amin, Rahman, or others, is unique and meaningful. That already implies that a child descended from a person (stamped) of the PKI did not dare to reveal his identity.

The author's emotional turmoil is seen in the following quote.

"Yes, even you and your whole family already think I'm crazy. Who is crazier? Me or your father and mother and all of you, their children? Even the fate of your dead grandfather who was killed and thrown in this river, also your grandmother who committed suicide on the banks of this river, never counted you, never became a concern for your family. Now, what are you going to ask of me?" He said, tapping my eardrum.

I paused, frowning.

"Come home. You don't need to care about me. It's not important whether I sing or not. After all, it doesn't change anything. I'm just a gravedigger and still a gravedigger. Until whenever," he said as he got up, walked, without turning his head.

The turmoil of the character of Me who could not let go of past events was emphasized in the closing of the short story: I was still silent, publishing at the riverbank. I looked at the surface of the water, which was getting increasingly red. Like blood. Bloodstorming. Related to the emotional wounds that arise as a result of the stigma of G-30 / SPKI descendants, we should develop a humanist sense and consider the historical truth. Based on this condition, according to Abdullah [12] in the Canadian Center of Science and Education the context of contemporary history in Indonesia in the case of the G-30 S / PKI history, it was found two interests, namely for historical truth and group goals.

\section{Conclusion}

Short story "Nyanyian Penggali Kubur" was built by utilizing songs that can be said to be legendary in the community. Although not directly related to the content of the story, at least the song -tracks become a vehicle to evoke sentimental emotional turmoil so bad considering the impact of a historical event in 1965 and thereafter. The time when people were gripped with fear so that they no longer led to human values. More than that, this short story stirs our feelings as children of the nation to answer rhetorical questions, when the stigma ends. 


\section{References}

[1] A. Setyagama, "Issn. 2355-6056," IUS J. Ilmu Huk., vol. 3, pp. 29-38, 2008

[2] J. Bahasa et al., "Reversing The Lens, Wacana Perlawanan Sejarah 1965 dalam Film The Act Of Killing," vol. II, no. 1, pp. 1-26, 2018.

[3] A. Alonso, "Thriving or Dividing? the Women's Movement and the Independence Referenda in Scotland and Catalonia," Polit. Gend., vol. 14, no. 3, pp. 460-482, 2018.

[4] C. Kondoahi, "Analisis Semiotika Pragmatik Lirik Lagu Krisis Kepercayaan dan Republik Sulap (Study Pada Komunitas Punk Street Di Manado),” J. Unsrat, vol. II, no. 4, p. 19, 2013.

[5] Aminnuddin, Stilistika, Pengantar Memahami Karya Sastra. Semarang: CV. IKIP Semarang Press., 1997.

[6] A. H. WM, Hermeneutika Sastra Barat dan Timur. Jakarta: Sadra, 2014.

[7] T. Christomy and U. Yuwono, Eds., Semiotika Budaya. Depok: Pusat Penelitian Kemasyarakatan dan Budaya, Direktorat Riset dan Pengabdian Masyarakat UI.

[8] R. Wellek and A. Warren, Teori Kesusastraan (Diterjemahkan Oleh Melani Budianta). Jakarta: Pustaka Jaya, 1989.

[9] G. . Susanto, Nyanyian Penggali Kubur. Semarang: Pata Press dan Fasindo Press, 2016.

[10] Universitas Psikologi, "Kisah Eric Fromm (Eksistensi Manusia) dan Tipe Kepribadian Sehat," 2018. [Online]. Available: https://www.universitaspsikologi.com/2018/07/kisah-eric-frommeksistensi-manusia-dan.html.

[11] W. Herlambang, Kekerasan Budaya Pasca 1965; Bagaimana Orde Baru Melegitimasi AntiKomunisme Melalu Sastra dan Film. Tangerang: Â Margin Kiri, 2013.

[12] A. Abdullah, "Contemporary History of Indonesia between Historical Truth and Group Purpose," Rev. Eur. Stud., vol. 7, no. 12, p. 179, 2015. 